\title{
Cultivation of Microalgae Monoraphidium sp., in the Plant Pilot the Grand Valle Bio Energy, for Biodiesel Production
}

\author{
Gisel Chenard Díaz ${ }^{1}$, Yordanka Reyes Cruz², René González Carliz², \\ Rosa C. Vitorino de Paula², Donato A. Gomes Aranda², Marcellus A. G. Dario', \\ Gustavo Saraiva Marassi' ${ }^{1}$, Nelson C. Furtado ${ }^{3}$ \\ ${ }^{1}$ Grand Valle Bio Energy Ltda., Rio de Janeiro, Brazil \\ ${ }^{2}$ Greentec Laboratory, School of Chemistry, Federal University of Rio de Janeiro, \\ Rio de Janeiro, Brazil \\ ${ }^{3}$ Brazilian Center for Physical Researches, Rio de Janeiro, Brazil \\ Email: gisemarina@yahoo.es
}

Received 7 May 2015; accepted 12 July 2015; published 16 July 2015

Copyright (C) 2015 by authors and Scientific Research Publishing Inc.

This work is licensed under the Creative Commons Attribution International License (CC BY). http://creativecommons.org/licenses/by/4.0/

(c) $\underset{\mathrm{EY}}{0}$ Open Access

\section{Abstract}

At present, Brazil imports approximately 11 billion liters/year of diesel. With the interruption of the works in the new Petrobras refineries, the projection is that by 2025 this volume will increase to 24.2 billion liters of diesel/year. In this sense, the biodiesel factory Grand Valle Bio Energy Ltda., located in the state of Rio de Janeiro, in conjunction with the FAPERJ makes some investments in technology development for the cultivation and use of microalgae as an alternative raw material in the production of biodiesel. Based on arguments previously said, this work presents the results of the microalgae cultivation Monoraphidium sp. in photobioreactors the pilot plant of the company. The installation with an area of $120 \mathrm{~m}^{2}$ is included with 2 open photobioreactors of type falling film $(20 \mathrm{~m} \times 1 \mathrm{~m})$, with a cascade of $18 \mathrm{~mm}$ and capacity of $4000 \mathrm{~L}$. The lineage cultivated is selected from previous ecophysiological studies that are identified as promising for biodiesel production by having a high potential for the production of lipids. This lineage is maintained at collection of the stock of cultures Laboratory of Green Technologies of the School of Chemistry/ UFRJ. The cultivation was performed in means ASM-1 (Gorham et al., 1964), initial pH 8.0, with aeration and circulation average of 8 hours a day during 19 days. The culture was started with an inoculum of $1 \times 10^{7} \mathrm{cel} / \mathrm{ml}$. The lipid production was determined in two phases of growth: on day 4 (exponential phase) and 15 day (stationary phase). For the determination and quantification of lipid content, two different methods were assessed for a sample of biomass, submitted to the same processes the separation and drying. The results showed the methodology of Bligh \& Dyer with modifications as the most efficient in extracting lipids. The total lipid content of the biomass Monoraphidium sp. was $30.58 \%$. The growth rate varied between $0.74 \pm 0.01$ and $0.68 \pm 0.02$. 


\section{Keywords}

\section{Cultivation, Photobioreactors, Microalgae, Biodiesel}

\section{Introduction}

At present, Brazil imports approximately 11 billion liters/year of diesel. With the interruption of the works in the new Petrobras refineries, the projection is that by 2025 this volume will increase to 24.2 billion liters of diesel/year. This new scenario of large diesel demand imported will allow the utilization of higher levels of biodiesel.

To meet the market that is expanding, the industry already studies expand the range of raw materials and technologies used. Microalgae besides being considered, at the discretion of numerous researchers as an important source of nutritional supplements and functional foods [1] [2], they are now presented as a raw material practically unexplored for the production of biofuels (biodiesel, ethanol and hydrogen) with ample opportunities for to be inserted under the model biorefinery [3]-[5].

Microalgae have an oil production potential 7 to 30 times higher than the typical oilseeds such as sunflower, castor bean, palm and soybeans; possibility of continuous production, with no period of planting and the off season; and carbon sequestration rate much higher than of the terrestrial plants. In this sense, the biodiesel plant Grand Valle Bio Energy Ltda., located in the state of Rio de Janeiro, of conjunction with the FAPERJ makes some investments in developing technology for the cultivation and use of microalgae as an alternative raw material in the production of biodiesel.

Additionally besides the obtaining biomass, two methodologies for the determination and quantification of lipid content were evaluated. The results showed the methodology Bligh \& Dyer with modifications as more efficient in the extraction of lipids when compared with the methodology Bligh \& Dyer with ultrasound. The growth curve showed that the culture grew exponentially from the beginning of cultivation until the 5th day of cultivation, and then entered in a deceleration phase, reaching between days 10 and 14 the phase stationary of growth.

\section{Materials and Methods}

\subsection{Materials}

We used the lineage of chloroficea gender: Monoraphidium sp. selected from studies ecophysiological previous as promising for biodiesel production for being potentially producing lipids. This lineage is maintained in the collection of cultures from Laboratory Technologies Greens (Greentec) of the School of Chemistry/UFRJ. Were ceded, $200 \mathrm{~L}$ of this culture for use as inoculum in the cultivators of the Unit Pilot Grand Valle Bio Energy Ltda.

The installation with an area of $120 \mathrm{~m}^{2}$, with 2 photobioreactors open sky of type film descendant of $20 \mathrm{~m} \times 1 \mathrm{~m}$, with waterfall of $18 \mathrm{~mm}$ and $4000 \mathrm{~L}$ capacity. The cultivation was performed in medium ASM-1 [6], pH 8.0, with airing and recirculation average of 8 hours for 19 days. The culture was initiated with an inoculum of $1 \times$ $10^{7} \mathrm{cel} / \mathrm{mL}$.

The microalgal biomass was concentrated by centrifugation (Figure 1). The moisture content of the resulting biomass was $87.6 \%$, determined by gravimetric analysis temperature of $110^{\circ} \mathrm{C}$ for $60 \mathrm{~min}$.

\subsection{Cell Growth}

Cell growth was accompanied through the counting the number of cells and dry weight on alternate days. The lipid production was determined in two phases of growth: on day 4 (exponential phase) and 15 days (stationary phase). The growth rate $(\mu)$ was determined according to the formula described in [7] shown in Equation (1):

$$
\mu=\left(\ln N_{2}-\ln N_{1}\right) /\left(t_{2}-t_{1}\right)
$$

where: 


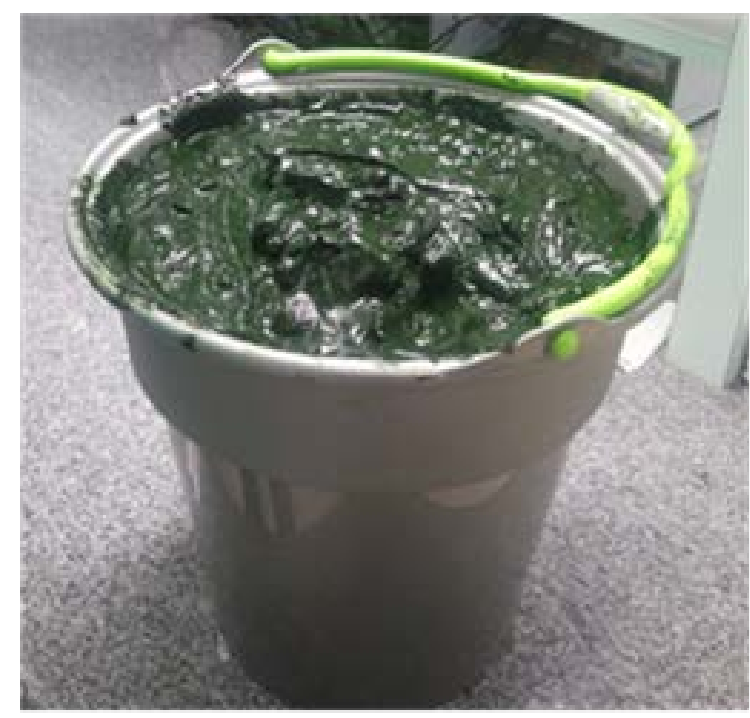

Figure 1. Wet biomass the microalgae Monoraphidium sp.

$\mu=$ rate of growth.

$N_{1}$ and $N_{2}=$ number of cells/mL at time $t_{1}$ (day zero) and $t_{2}$ (8 day).

It was also determined the maximum performance of the cultures $(R)$ which is the maximum number of cells obtained at the end of cultivation subtracted from number of cells in the initial inoculum.

\subsection{Chemical Characterization of the Biomass}

\subsubsection{Analysis of Dry Weight}

To determine the dry weight of the biomass was followed the following protocol developed by technicians the management bioproducts from CENPES/PETROBRAS: was calcined a membrane at $575^{\circ} \mathrm{C}$ for $1 \mathrm{~h}$ to remove humidity content; placed himself in desiccator and annotated its initial mass (mi); were filtered $10 \mathrm{ml}(\mathrm{Vf})$ of the microalgae culture in the membrane; then placed in a stove at $65^{\circ} \mathrm{C}$ for $1 \mathrm{~h}$; cooled in desiccator and it was registered its final mass $(m f)$ for determination of dry weight and, consequently, the content of dry biomass and moisture content, according to Equations (2)-(4).

For cashing the values from ash the final dry weight, the membranes with dry biomass were calcined at $575^{\circ} \mathrm{C}$ for 1 hour, cooled and weighed. The dry weight determination was performed in triplicate. where:

$$
\begin{gathered}
\mathrm{X}=\frac{(m f-m i) \times 1000 \times F D}{V f} \\
\mathrm{DM}=\frac{\mathrm{X}}{10} \\
\mathrm{CM}=100-\mathrm{DM}
\end{gathered}
$$

$\mathrm{X}=$ concentration of biomass or dry weight in $\mathrm{g} / \mathrm{L}$;

$m i=$ mass of calcined membrane without the filtered microalgae (initial mass);

$m f=$ membrane mass with dry microalgae (final weight);

$V f=$ volume of culture of microalgae filtered;

$\mathrm{FD}=$ dilution factor;

$\mathrm{DM}=$ dry matter content;

$\mathrm{CM}=$ moisture content.

\subsubsection{Moisture Content Analysis}

In the moisture content analysis of the biomass after centrifugation, it was used the protocol most generally em- 
ployed for this type of analysis, described following: placed himself the watch-glass in an furnace at $110^{\circ} \mathrm{C}$ for 1 hour to remove moisture; cooled in a desiccator; registered the mass of the watch-glass; was weighed about 0.5 g of lyophilized sample or $2 \mathrm{~mL}$ of the wet sample $\left(m_{2}\right)$; and placed in an furnace at $65^{\circ} \mathrm{C}$ until constant weight (24 hours). After this time interval, it was placed the watch-glass with dry sample in a desiccator, cooled and registered the final mass $\left(m_{1}\right)$. The moisture content and solids were determined by the Equations (5) and (6). The determination of moisture content of the biomass was performed in triplicate.

where:

$$
\begin{gathered}
\mathrm{CM}=100\left(1-\frac{m_{1}}{m_{2}}\right) \\
\mathrm{CS}=100 \frac{m_{1}}{m_{2}}
\end{gathered}
$$

$\mathrm{CM}=$ moisture content (\%);

CS = solids content $(\%)$;

$m_{1}=$ sample mass after drying (g);

$m_{2}=$ initial weight of sample (g).

\subsubsection{Determination of Protein Content}

The protein determination in this study was performed according to the Kjeldahl method [8], which is based on the determination of the total organic nitrogen, which protein will be converted by means of a conversion factor. The conversion factor used was 6.25, used for food in general [9].

\subsubsection{Determination of Carbohydrates}

For perform analysis were utilized $2 \mathrm{mg}$ of cell, dry weight, of the microalgae in triplicate. The mass of the sample used for analysis was estimated from the dry mass of cells obtained according 2.3.1. After weighing were added $4 \mathrm{~mL}$ of water MilliQ on the sample, and this subjected to homogenization for 30 minutes.

Intracellular carbohydrates and extracellular were quantified according to the methodology of [10], which is based in fact from what complex sugars, and their derivatives, including methyl esters with groups reducers free or potentially free when treated with phenol and concentrated sulfuric acid gives yellow-orange coloration, with a sensitive reaction and coloring stable.

The method is simple, rapid, sensitive and with reproducible results [11], it is not a selective analysis, and it involves any type of carbohydrate. To quantify the carbohydrates, for spectrophotometer, was constructed a curve Standard glucose.

\subsubsection{Lipid Content}

They were evaluated for extracting total lipid two different methodologies for a sample of biomass microalgae Monoraphidium sp., submitted to the same processes the separation and drying.

The biomass used for extraction generated from microalgal cultivation it should be centrifuged at $8000 \mathrm{rpm}$ for 10min, washed twice with distilled water in order to be used. In the case of wet biomass, the lipids should be extracted after centrifugation, not being suitable storing the biomass, and determined the moisture present in the sample.

1) Method Bligh \& Dyer (1959)-with ultrasound

Approximately $500 \mathrm{mg}$ of sample $\left(\mathrm{m}_{1}\right)$, weighed in analytical balance, were macerates in crucible porcelain with $30 \mathrm{~mL}$ of chloroform. After macerating were added $10 \mathrm{~mL}$ of methanol to the mixture, which was transferred to falcon tube a 50mL with screw cap and maintained in an ultrasound bath $(40 \mathrm{kHz})$ for $30 \mathrm{~min}$. Then was added around $12 \mathrm{~mL}$ of aqueous $1 \% \mathrm{NaCl}$ to the tube, the contents were transferred to an extraction funnel and subjected to vigorous agitation to phase separation.

The phase lipid green (lower) it was filtered to remove particulates and the solution collected in flask containing the lipids he was transferred to desiccator for cooling, after was weighed for determination of mass $\left(m_{2}\right)$. The lipid content (CL) determined in triplicate it is calculated from the Equation (7). The mass obtained divided by sample quantity used it results in content lipid extracted from the cells ( $g \cdot g^{-1}$ dry biomass) [12] [13]. 


$$
\mathrm{CL}=100 \frac{m_{2}}{m_{1}}
$$

2) Lipid content

The lipid extraction is done in two steps, at the first the sample is digested with hydrochloric acid to break through the wall cellular and at the second the lipids are extracted with the mixture of solvents [14].

In the first step based in the digestion of the sample with hydrochloric acid, was weighed $400 \mathrm{mg}$ of the sample directly in flask of extraction of Mojonnier $\left(m_{2}\right)$. Were added $5 \mathrm{~mL}$ of $8 \mathrm{M}$ hydrochloric acid solution and agitated to promote the dispersion of the material. Then the sample was heated in a water bath at $80^{\circ} \mathrm{C}$ for 1 hour to complete digestion of the cells. Posteriorly leave the flask to rest for 10 minutes at $25^{\circ} \mathrm{C}$ and centrifuged at 2000 rpm for 15 minutes to separate the biomass and the acid residue. After digestion remove the residual acid and continue with the flask which contains the biomass to step the extraction of lipids.

In the second step were added to the flask Mojonnier the mixture of solvents, methanol, chloroform and water in the proportions (4:4:3.6), stirred for 10 minutes and centrifuged at $2000 \mathrm{rpm}$ for 15 minutes. After centrifugation were obtained 3 phases containing off the lower phase where the lipids are dissolved and chloroform (which we must recover) the middle phase containing biomass extracted and the upper phase composed of water and methanol.

Pour the ethereal phase (inferior) to the beaker previously weighed $\left(\mathrm{m}_{1}\right)$ and repackage it in thermostatic bath at $65^{\circ} \mathrm{C}$ until complete evaporation of the solvent. In the phases remaining in the flask Mojonnier (biomass, methanol, water) do re-extraction of lipids which are still in biomass by adding $4 \mathrm{ml}$ of $10 \%$ solution v/v methanol in chloroform, shake and centrifuge at $2000 \mathrm{rpm}$ for 15 minutes. This step is essential for migration of lipids withheld in the residue of microalgae for the solvent. Repeat the procedure for re-extraction one more time and remove off the lower phase where are lipids and join with the first extract (ethereal phase). Finally leave the beaker in a water bath at $65^{\circ} \mathrm{C}$, for the solvent evaporation. After removal of the solvents by evaporation, put the beaker in oven at $102^{\circ} \mathrm{C} \pm 2^{\circ} \mathrm{C}$ for 1 hour. Cool down in desiccator and weigh. Repeat drying and weighing until constant mass $\left(m_{3}\right)$. The content of lipids (CL) as determined in triplicate is calculated by the Equation (8).

$$
\mathrm{CL}=100 \frac{m_{3}-m_{1}}{m_{2}}
$$

\subsubsection{Lipid Profile of Microalgae Biomass}

To perform analysis of lipid profile the sample extracted in item 2.4.1.2 was submitted to reaction the methanolysis according to the methodology described next: Were used 300mg lipid sample. After the sample was subjected to methanolysis using $2 \mathrm{~mL}$ methanol with $5 \% \mathrm{HCl}$ at $75^{\circ} \mathrm{C}$ for 10 minutes in water bath, this step was performed in a closed bottle to prevent evaporation. Then, a phase containing the fatty acids esterified was separated by adding $2 \mathrm{~mL}$ of distilled water and $2 \mathrm{~mL}$ of hexane. The top hexane phase was collected and transferred to a glass bottle, then placed in oven at $60^{\circ} \mathrm{C}$ for solvent evaporation and concentration of the sample (methyl ester) [15].

After methanolysis be determined for the lipid profile and identification of methyl esters of fatty acids the according with standard EN14103, was performed by comparison of retention times of the sample constituents with the respective standard fatty acid methyl esters from Sigma $\left(\mathrm{C}_{4: 0}-\mathrm{C}_{24: 0}\right)$ and the quantification (\% $\left.\mathrm{m} / \mathrm{m}\right)$ was performed relative to an internal standard, methyl nonadecanoate (C19:0), using a gas chromatograph, Shimadzu GC2014 coupled to a flame ionization detector (FID), injector of type split/splitless and a capillary column DB-23 (30 $\mathrm{m} \times 0.25 \mathrm{~mm} \times 0.25 \mu \mathrm{m})$ mark Agilent, to the following conditions: injector: $250^{\circ} \mathrm{C}$, flow 50:1; Arrastre gas: Hydrogen; Pressure of the carrier stream: $1 \mathrm{~mL} / \mathrm{min}$; Detector: $280^{\circ} \mathrm{C}$, the auxiliary gas (make-up) was $\mathrm{N}_{2}(30 \mathrm{~mL} / \mathrm{min}), \mathrm{H}_{2}(30 \mathrm{~mL} / \mathrm{min})$ and synthetic air $(30 \mathrm{~mL} / \mathrm{min})$. Programming of the oven temperature: $60^{\circ} \mathrm{C}$ for 2 minutes, $60^{\circ} \mathrm{C}$ to $200^{\circ} \mathrm{C}$ (gradient of $10^{\circ} \mathrm{C}$ per minute); $200^{\circ} \mathrm{C}$ to $240^{\circ} \mathrm{C}$ (gradient of $5^{\circ} \mathrm{C}$ per min) and isothermal for 15 minutes. Analyses were performed for $30 \mathrm{~min}$.

\section{Results}

\subsection{Growth Curve the Microalgae Monoraphidium sp.}

The growth curve (Figure 2) shows that culture grew an exponential way accelerated from the beginning to the 
5 day of culture, then got into a slowdown phase, reaching between days 10 and 14 the stationary phase of growth. Although cell death have started from the 10 day of culture, the biomass continued to grow until the 19 day of culture, that is, the remaining cells have become more dense, probably occurred the accumulation of some intracellular component in the physiology of the cells by the nutritional limitation, intensifying the synthesis of lipids. The growth rate in cultivation were between $0.74 \pm 0.01$ and $0.68 \pm 0.02$ and the maximum yield obtained was 96.3 (Table 1).

According to the literature the coexistence of different species in an environment occurs when the dispute of resources available does not include that which is limiting for their growth [16]. Thus, the species which has higher absorption capacity of the nutrient available will have better growth conditions [17] [18].

\subsection{Chemical Characterization of the Biomass}

For obtaining the dry weight of the microalgae, was used a concentrated culture which was diluted 1:200 (FD = 200) and $10 \mathrm{~mL}$ of this were filtered through a membrane according to the methodology described in item 2.3.1. The biomass concentration obtained was $124.0 \pm 0.72 \mathrm{~g} / \mathrm{L}$, equivalent to a dry matter content of $12.4 \% \pm 0.07 \%$. In Figure 3 can be displaying images of microalgae Monoraphidium sp., before and after drying in procedure dry weight. To determine the moisture content, it weighed approximately $2 \mathrm{~mL}$ of wet biomass, according to the item 2.3.2. and there was obtained a moisture content of $87.6 \% \pm 0.07 \%$.

In the determination and quantification of the lipid content were evaluated the methodologies Bligh \& Dyer with ultrasound and Bligh \& Dyer with modifications in the biomass of microalgae Monoraphidium sp.

The methodology of Bligh \& Dyer with modifications, although require more time for analysis, it was more efficient in the extraction of lipids $(30.58 \% \pm 0.02 \%, n=2)$ compared to Bligh \& Dyer the methodology with ultrasound $(15.24 \% \pm 0.01 \%, n=2)$, because the utilization of hydrochloric acid in the first extraction secured

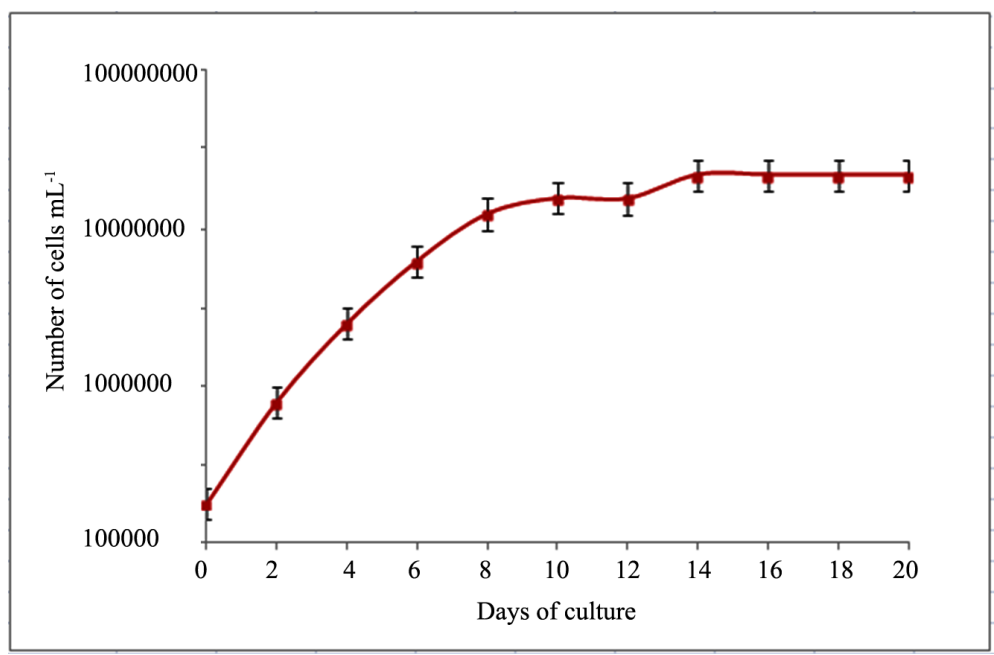

Figure 2. Growth curve of microalga Monoraphidium sp. The results represent the mean $(n=3) \pm$ standard error.

Table 1. Values of the growth curve of microalgae Monoraphidium sp. mean between triplicate followed the standard error.

\begin{tabular}{cc} 
Parameters & Cultivation \\
\hline$N 0\left(\times 10^{7}\right.$ cells $\left.\cdot \mathrm{mL}^{-1}\right)$ & 1.8 \\
$N$ máx. $\left(\times 10^{7}\right.$ cells $\left.\cdot \mathrm{mL}^{-1}\right)$ & $176.6( \pm 2.5)^{*}$ \\
$\mu$ & $0.82( \pm 0.01)$ \\
$R$ & $96.3( \pm 2.3)^{*}$ \\
Interval of the exponential phase (days) & $0-8$ \\
\hline
\end{tabular}

N0 e Nmáx.: Number of initial cells and maximum, $\mu$ : growth rate, $R$ : maximum rate of growth; ${ }^{*}$ indicates significant difference $(\mathrm{P}<0.05)$. 
the rupture of the cell wall and subsequently at the second by using a solvent mixture (methanol and chloroform) favored the full extraction of lipids [14] [19]. The lipids produced by the microalgae are generally neutral lipids with a high degree of saturation, becoming an appropriate source of raw material for biodiesel production [20]. Table 2 shows the chemical components of the obtained biomass. Was evident the presence of significant quantities of protein and carbohydrates.

The typical composition the biomass Monoraphidium sp. is: lipid content of $19 \%-35 \%$, protein $28 \%-45 \%$ and carbohydrates $17 \%$ - 25\%, in relation to the dry weight of biomass [21]-[23]. The percentage of lipids reported in the literature for microalgae this genre Monoraphidium sp., if corresponds to the value of total lipids obtained by the methodology of Bligh \& Dyer modified (30.58\%).

The lipid profile and composition of the methyl esters (\%) of microalgal biomass Monoraphidium sp., obtained through analysis the esters by gas chromatography, is shown in Figure 4. According to these data, the specie presented the following distribution of saturated fatty acids (SAFA) and unsaturated (MUFA and PUFA): content SAFA > PUFA > MUFA. It is observed that the highest values refer to SAFAs, mainly the C16:0 (palmitate). In relation to the PUFAs It was observed mainly represented by C18:3 (linolenate). As to the MUFAs was also identified in high amounts C18:1 (oleate).

The results were compatible with those encountered in previous works, where palmitic acid was identified as the predominant in most species of microalgae grown in fresh water [24] [25]. What to do does not prevent the possible utilization of the microalgae as raw material for the production of biodiesel. The methyl esters produced from the extracted lipid fraction the wet biomass of Monoraphidium sp., meets the specification for content of methyl esters established by in standard EN 14214 and RANP $n^{\circ} 14$. The content of methyl esters (\%) was $97.6 \%$.

\section{Conclusions}

The production of biodiesel requires a significant amount of biomass, lipid content and fatty acids of interest of medium chain (C16 and C18), constituting the parameter more direct and precise to evaluate the potential of microalgae as raw material for biodiesel production, since neither all of the compounds soluble in organic solvents used in the extraction can be converted into biodiesel. In this context, the results obtained in the cultivation of microalgae Monoraphidium sp., in the open photobioreactor, show the potential of this microalgae for the production of biodiesel.

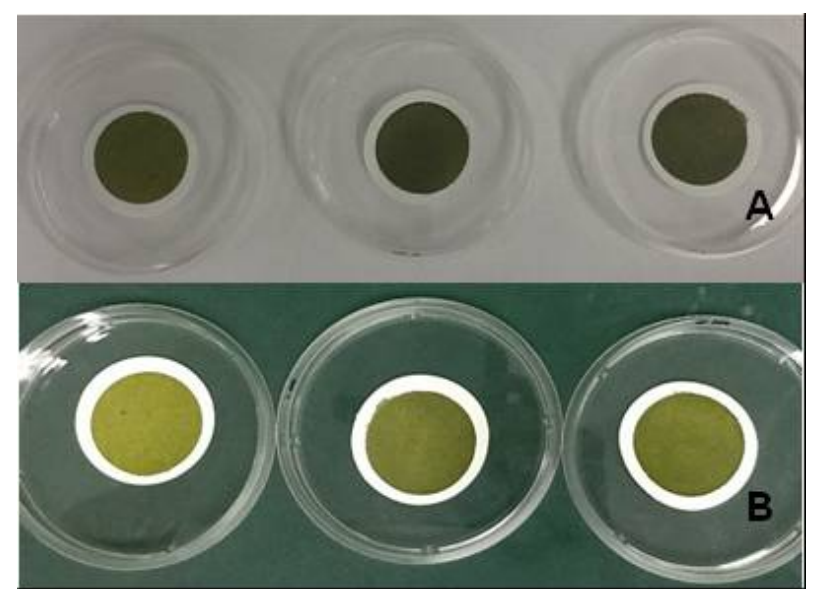

Figure 3. Biomass Monoraphidium sp. before (A) and after (B) drying in procedure dry weight.

Table 2. Biochemical composition of the biomass of microalgae Monoraphidium sp.

\begin{tabular}{|c|c|c|c|}
\hline \multicolumn{4}{|c|}{ \% IN Relation to Dry Weight of Biomass } \\
\hline \multirow{2}{*}{ Monoraphidium sp. } & Lipids & Protein & Carbohydrates \\
\hline & $30.58 \pm 0.05$ & $43.84 \pm 0.01$ & $25.58 \pm 0.05$ \\
\hline
\end{tabular}




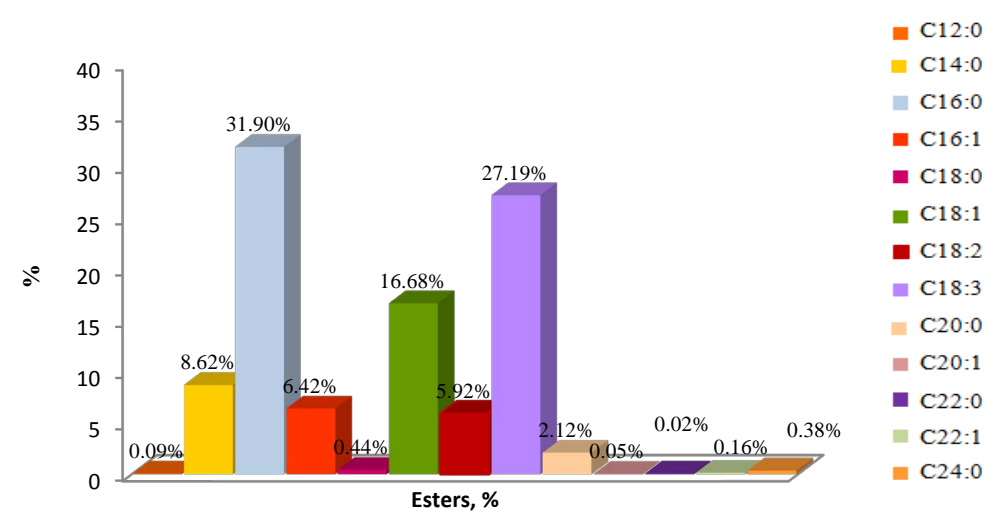

Figure 4. Lipid profile and composition of methyl esters (\%) of biomass Monoraphidium sp., identification: C12:0(0.09\%), C14:0(8.62\%), C16:0 (31.90\%), C16:1 (6.42\%), C18:0 (0.44\%), C18:1 (16.68\%), C18:2 (5.92\%), C18:3 (27.19\%), C20:0 (2.12\%), C20:1 (0.05\%), C22:0 (0.02\%), C22:1 (0.16\%), $\mathrm{C} 24: 0$ (0.38\%).

The lipid profile and composition of methyl esters are considered ideal for the production of biodiesel, complying with the for content methyl esters specification for biodiesel, established by standard EN 14214 e na RANP $n^{\circ} 14$.

\section{Acknowledgements}

We acknowledge financial support from Faperj.

\section{References}

[1] Shimizu, Y. (2003) Microbial Metabolism. Current Opinion in Microbiology, 6, 236-243. http://dx.doi.org/10.1016/S1369-5274(03)00064-X

[2] Spolaore, P., Joannis-Cassan, C., Duran, E. and Isambert, A. (2006) Commercial Applications of Microalgae. Journal of Bioscience and Bioengineering, 101, 87-96. http://dx.doi.org/10.1263/jbb.101.87

[3] Huang, G., Chen, F., Wei, D., et al. (2010) Biodiesel Production by Microalgal Biotechnology. Applied Energy, 87, 3846. http://dx.doi.org/10.1016/j.apenergy.2009.06.016

[4] Amaro, H.M., Guedes, A.C. and Malcata, F.X. (2011) Advances and Perspectives in Using Microalgae to Produce Biodiesel. Applied Energy, 88, 3402-3410. http://dx.doi.org/10.1016/j.apenergy.2010.12.014

[5] Kee, L.M. and Lee, K.T. (2012) Microalgae Biofuels: A Critical Review of Issues, Problems and the Way Forward. Biotechnology Advances, 30, 673-690. http://dx.doi.org/10.1016/j.biotechadv.2011.11.008

[6] Gorham, P.R., McLachlan, R.W. and Hammer, U.T. (1964) Isolation and Culture of Toxic Strains of (Lyngb.) de Breb. Anabaena flos-aquae. Verhandlungen der Internationalen Vereinigung fur Theoretische und Angewandte Limnologie, 15, 796-804.

[7] Fogg, G.E. and Thake, B. (1987) Algae Cultures and Phytoplankton Ecology. 3rd Edition, The University of Winsconsins Press, Ltd., London.

[8] Association of Official Analytical Chemists-(AOAC) (1998) Official Methods of Analysis of AOAC International. 16th Edition, v.2, Washington DC, 1018 p.

[9] Cecchi, H.M. (2005) Fundamentos teóricos e práticos em análise de alimentos. 3rd Edition, Unicamp, Campinas, 207.

[10] Dubois, M., Gilles, K.A., Hamilton, J.K., Rebers, P.A. and Smith, F. (1956) Colorimetric Method for Determination of Sugars and Related Substances. Analytical Chemistry, 28, 350-356. http://dx.doi.org/10.1021/ac60111a017

[11] Demiate, I.V., Wosiacki, G., Czelusniak, C. and Nogueira, A. (2002) Determinação de açucares redutores e totais em alimentos. Comparação entre métodos colorimétricos e titulométricos. Exact and Soil Scienciens, Agrárian S. and Engeneering, 8, 65-78.

[12] Lourenço, S.O. (2006) Cultivo de microalgas marinhas: Princípios e aplicações. RiMa, São Carlos, 606.

[13] Brum, A.A.S., de Arruda, L.F. and Regitano-D’arce, M.A.B. (2009) Métodos de extração e qualidade da fração lipídica 
de matérias-primas de origem vegetal e animal. Química Nova, 13, 849-854. http://dx.doi.org/10.1590/S0100-40422009000400005

[14] Bligh, G. and Dyer, W. (1959) A Rapid Method for Total Lipid Extraction and Purification. Canadian Journal of Biochemistry and Physiology, 37, 911-917. http://dx.doi.org/10.1139/059-099

[15] Yoo, C., Jun, S.Y. and Lee, J.Y. (2010) Selection of Microalgae for Lipid Production under High Levels Carbon Dioxide. Bioresource Technology, 101, S71-S74. http://dx.doi.org/10.1016/j.biortech.2009.03.030

[16] Begon, M., Harper, J.L. and Townsend, C.R. (1995) Ecología: Individuos, poblaciones y comunidades. Ediciones Omega, Barcelona.

[17] Reynolds, C.S. (2006) Ecology of Phytoplankton (Ecology, Biodiversity and Conservation). Cambridge University Press, Cambridge. http://dx.doi.org/10.1017/CBO9780511542145

[18] Marinho, M.M. and Azevedo, S.M.F.O. (2007) Influence of N/P Ratio on Competitive Abilities for Nitrogen and Phosphorus by Microcystis aeruginosa and Aulacoseira distans. Aquatic Ecology, 41, 525-533. http://dx.doi.org/10.1007/s10452-007-9118-y

[19] Carolino, L. do R.V.C. (2011) Cultivo de microalgas unicelulares para determinação da produção lipídica e sequestro de carbono. ULisboa Faculdade de Ciências Departamento de Biologia Vegetal, Mestrado de Biologia Celular e Biotecnologia, 91.

[20] Rawat, I., Ranjith Kumar, R., Mutanda, T. and Bux, F. (2011) Dual Role of Microalgae: Phycoremediation of Domestic Wastewater and Biomass Production for Sustainable Biofuels Production. Applied Energy, 88, 3411-3424. http://dx.doi.org/10.1016/j.apenergy.2010.11.025

[21] Reyes, Y., Chenard, G., Aranda, D., Gorgônio, C., Duartes, A., João, R., Balcellar, L. and Fortes, M. (2012) Biodiesel Production by Hydroesterification of Microalgal Biomass Using Heterogeneous Catalyst. Natural Science, 4, 778-783. http://dx.doi.org/10.4236/ns.2012.410102

[22] PI000479 (2012) Processo de hidroesterificação para a produção de biodiesel a partir de biomassa úmida de microalgas.

[23] Jaruwan, C., Wanida, P., Afrasiab, K., Imrana, N.S., Werasit, S. and Pramuk, P. (2014) Screening of High-Lipid Content Microalgae for Biodiesel Production. TSB, 16-18.

[24] Colla, L.M., Bertolini, T.E. and Costa, J.A.V. (2004) Fatty Acids Profile of Spirulina platensis Grown under Different Temperatures and Nitrogen Concentrations. Zeitschrift für Naturforschung C, 59, 55-59. http://dx.doi.org/10.1515/znc-2004-1-212

[25] Olguín, E., Galicia, S. and Angulo-Guerrero, O. (2001) The Effect of Low Light Flux and Nitrogen Deficiency on the Chemical Composition of Spirulina sp. (Arthrospira) Grown on Digested Pig Waste. Bioresource Technology, 77, 1924. http://dx.doi.org/10.1016/S0960-8524(00)00142-5 